\title{
OPEN
}

\section{Author Correction: Noninvasive Electroencephalogram Based Control of a Robotic Arm for Reach and Grasp Tasks}

\author{
Jianjun Meng, Shuying Zhang, Angeliki Beyko, Jaron Olsoe, Bryan Baxter \& Bin He \\ Correction to: Scientific Reports https://doi.org/10.1038/srep38565, published online 14 December 2016
}

This Article contains a typographical error in the spelling of the author Angeliki Beyko, which is incorrectly given as Angeliki Bekyo.

\begin{abstract}
(c) Open Access This article is licensed under a Creative Commons Attribution 4.0 International License, which permits use, sharing, adaptation, distribution and reproduction in any medium or format, as long as you give appropriate credit to the original author(s) and the source, provide a link to the Creative Commons license, and indicate if changes were made. The images or other third party material in this article are included in the article's Creative Commons license, unless indicated otherwise in a credit line to the material. If material is not included in the article's Creative Commons license and your intended use is not permitted by statutory regulation or exceeds the permitted use, you will need to obtain permission directly from the copyright holder. To view a copy of this license, visit http://creativecommons.org/licenses/by/4.0/.
\end{abstract}

(c) The Author(s) 2020 